\title{
INKUBATOR KOTA
}

\author{
Marcellus Rafi ${ }^{1)}$, Agustinus Sutanto ${ }^{21}$ \\ 1)Program Studi S1 Arsitektur, Fakultas Teknik, Universitas Tarumanagara, humas@untar.ac.id \\ 2)Program Studi S1 Arsitektur, Fakultas Teknik, Universitas Tarumanagara, gak.architects@gmail.com
}

\begin{abstract}
Abstrak
Keterhubungan sosial dalam kehidupan manusia semakin memudar dalam alam bawah sadar. Generasi Milenial yang dikenal dengan kecenderungan selalu berkolaborasi, pun tidak acuh untuk menyinergikan berbagai golongan ekonomi-sosial yang kontras. Begitpun arsitek, sebagian besar lebih memilih untuk menggeluti desain yang fantastis dengan bentukan yang melintir daripada interelasi terhadap sosial. Alhasil Kota Jakarta saat ini yang dipenuhi dengan bangunan pencakar langit dan mal megah dengan asas "Form Follow Finance". Menanggapi isu tersebut, proyek ini memiliki visi untuk melihat arsitektur dengan mengedepankan ide "Sustainability in Society". Melalui metode riset 'agen keruangan' dan 'keseharian berurbanisme', disertai metode desain 'Hybridization of Architectural Programming'; Jenis bangunan yang dirancang diharap mampu merepresentasi kepekaan seorang arsitek dalam melihat socio-spatialitas dengan kedalaman berpikir yang dapat dipertanggungjawabkan. Hingga doperoleh kontent ruang yang terdiri dari: Public space, food market, community learning space, dan living food farming. Keempat program tersebut muncul atas hasil penelitian dan metodologi yang didasari atas prinsip kolaboratif dan sinergi, menjadi sebuah 'prototipe' elemen kota baru yang terintegrasi dengan elemen lama disekelilingnya. Mampu berkontribusi bagi masyarakat untuk mengupayakan keseimbangan antara lingkungan alam yang sudah terdominasi dan terkontaminasi oleh lingkungan buatan. Hasil proyek ini menunjukan bahwa dengan ketajaman berpikir dan kepekaannya, arsitektur dapat turut serta berkontribusi dalam mengupayakan kesejahteraan manusia dalam sosial dan ekonomi yang berbeda sekaligus menjaga kelestarian lingkungan demi lebih baiknya keberlangsungan kota di masa mendatang.
\end{abstract}

Kata Kunci: Agen Keruangan Sosial; Kepekaan; Kontribusi; Kolaboratif; Sinergi

\begin{abstract}
Social relation in human life fades subconsciously. Millennial which known for its tendency to always collaborate, is also not even try to synergize the compartmentalized way of life in a contrasted social-economic class. Even architects, most prefer to wrestle with fantastic designs rather than inovate the social interrelation. As a result, the city of Jakarta is filled with magnificent buildings with the principle of "Follow Finance Form". Responding to the issue, this project has a vision to see architecture from another perspective by putting forward the idea of "Sustainability in Society". Through research methods, 'Spatial Agency' and 'Everyday Urbanism', accompanied by a design method 'Hybridization of Architectural Programming'; The type of building is expected to be able to represent the sensitivity of an architect in seeing socio-spatiality with the depth of thinking. The content is correspondingly which consists of: public space, food market, community learning space, and living food farming. The four programs emerged from research results and methodologies, based on collaborative and synergy principles, become a prototype of new city elements integrated with old elements around it. Able to contribute fully to the community to foster a balance between the natural environment that has been dominated and contaminated by manmade environment. The results of this project show that with the sharpness of thinking and sensitivity, architecture can contribute to the efforts of human welfare in different social and economic conditions while maintaining environmental sustainability for the better sustainability of the city in the future.
\end{abstract}

Key Words: Awareness; Collaboration; Contribution; Spatial Agency; Synergy 


\section{PENDAHULUAN}

Sejak dahulu manusia hadir mengisi ruang-ruang di dunia ini, kehidupan berlangsung dengan saling berinteraksi dan menjalin hubungan timbal balik satu sama lain. Sebab itulah entitas manusia dinyatakan sebagai makhluk sosial yang senantiasa hidup berkolaborasi secara dinamis. Yuval Noah Harari, seorang sejarawan yang popular menulis buku 'Sapiens: A Brief History of Mankind' memberikan pernyataan yang sangat luar biasa tentang manusia, bahwa:

Seventy-thousand years ago, our ancestors were insignificant animals. The most important thing to know about prehistoric humans is that they were unimportant. Their impact on the world was not much greater than that of jellyfish, fireflies, or woodpeckers. Today, in contrast, we control this planet.

The real difference between us and other animals is on the collective level. Humans control the world because we are the only animal that can cooperate flexibly in large numbers. Only Homo sapiens can cooperate in extremely flexible ways with countless numbers of strangers. Cooperation is not always nice, of course. Yet how come humans alone of all the animals are capable of cooperating flexibly in large numbers, be it in order to play, to trade or to slaughter? The answer is our imagination. We can cooperate with numerous strangers because we can invent fictional stories, spread them around, and convince millions of strangers to believe in them. As long as everybody believes in the same fictions, we all obey the same laws, and can thereby cooperate effectively. ${ }^{1}$

Pernyataan tersebut sejalan dengan karakteristik generasi milenial yang cenderung bekerja secara kolaboratif, koperatif, dan fleksibel. Pertanyaan adalah, apakah betul; sebesar apa kolaborasi tersebut sudah terjalin antar sesame manusia? Apakah hanya dalam kelompokkelompok individu? Mampukah era milenium ini membangun kerjasama secara luas diberbagai golongan kelas ekonomi yang berbeda; Sejalan dengan konsep ideologis makhluk sosial, yakni organisme hidup sekaligus struktur sosial kemasyarakatan yang senantiasa berupaya mempertahankan stabilitas dan keselarasan hidup bersama.

Kerjasama dan rasa penghargaan antar golongan kelas ekonomi sosial yang berbeda harus diupayakan bersama secara nyata. Dengan kemajuan konsep ekonomi kreatif yang sedang marak dilaksanakan berbasis kerakyatan dan kesejahteraan ekonomi bangsa, seharusnya entitas Usaha Mikro Kecil Menengah (UMKM) dapat semakin ditumbuh kembangkan melalui pemberdayaan yang kreatif dan proaktif. Sehingga keselarasan antar golongan dapat tercipta dalam mengisi ruang kota dan hidup berdampingan secara harmonis. Lantas sebagai arsitek, seberapa besar kepekaan kita menanggapi kebiasaan dan perilaku (behavior) pelaku kegiatan ekonomi kreatif kelas kecil-menengah di era milenial; Dan bagaimana arsitektur dapat memberi dampak terhadap aktivitas (activity), ruang (space), dan program (programming) yang hendak mewadahi kegiatan usahanya?

Dengan latar pemikiran menyangkut kepentingan sosial, paham arsitektur terhadap ruang kota (urban) dikeseharian memiliki andil yang besar dalam perencanaan dan perancangannya. Penggabungan aktivitas dan interelasi antara arsitektur dalam ruang kota harus betul-betul menjadi landasan dasar dalam berinovasi dan pengambilan keputusan programatika ruang didalamnya. Tak lupa dengan kemajuan teknologi (machines) yang mampu menghapus berbagai batas keterjangkauan dan ikut serta menciptakan tipologi (typology) baru dengan integrase ruang didalamnya. Sehingga kelak menghasilkan arsitektur yang mampu berkontribusi bagi kebaikan komunitas sektitarnya, berkelanjutan, dan kontekstual.

\section{Tujuan dan Makna Proyek: Inkubator Kota}

Inkubator (Incubator: an organization or place that aids the development of new business ventures especially by providing low-cost commercial space, management assistance, or shared

\footnotetext{
${ }^{1}$ Yuval Noah Harari, "Why Humns Run the World", diakses melalui reaman ulang TED Talks di Youtube, diakses pada 30 Januari 2019, pukul 08.20.
} 
services. ${ }^{2}$ ) diambil sebagai judul dari proyek ini, sebab dari definisinya membenang merahi tujuan besar (visi) proyek ini. Dalam pengertiannya ia merupakan sebuah generator keruangan, yang hadir untuk mengembangkan, mengolah, dan mengupayakan lingkungan perkotaan disekitarnya berkolaborasi dan bersinergi. Hal-hal yang digenerasikan meliputi integrasi antar elemen perkotaan lama dan baru, pelaku-pelaku usaha informal, dan korelasi antara lingkungan buatan dan alam.

Visi dari proyek ini sematang mungkin dipikirkan, untuk mengasah kepekaan arsitek terhadap interelasi subjek dan objek yang sudah ada di kehidupan nyata demi terciptanya kesejahteraan sosial dan lingkungan yng lebih baik. "Construction is the art of making a meaningful whole out of many parts." (1998, Peter Zumthor). Dialog antara ruang dan prilaku manusia di generasi milenial baru sebagian dari banyak partikel-partikel kehidupan lain yang dapat dikorelasikan. Untuk itu ketajaman berpikir (critical thinking) dan kerangka teoritis (theoritical framework) menjadi pondasi dasar yang harus dibangun demi keberhasilan dan kredibilitas konsep yang memaknai proyek ini.

\section{KAJIAN LITERATUR}

\section{Tinjauan Umum: Peluang dan Momentum}

Tema milenial hadir sebagi fenomena yang sedang marak dibicarakan dewasa ini. Dalam kesempatan kali ini, konsep yang dibangun harus didasari pada kondisi nyata yang sedang terjadi di era milenium tersebut. Untuk itu diperlukan ketajaman pikiran dan wawasan yang terbuka untuk mengambil sebuah latar yang memiliki korelasi dengan visi proyek ini. Tujuannya agar visi yang diutaran bukan hanya sekedar pragmatisme yang utopis di dunia angan-angan saja.

\section{Ekonomi Kreatif}

Ekonomi kreatif pertama kali diperkenalkan oleh John Howkins dalam bukunya The Creative Economy: How People Make Money from Ideas. Beliau mendefinisikan ekonomi kreatif sebagai the creation of value as a result of idea. ${ }^{3}$ Beliau juga menjelaskan ekonomi kreatif sebagai kegiatan ekonomi dalam masyarakat yang menghabiskan sebagian besar waktunya untuk menghasilkan ide, tidak hanya melakukan hal-hal yang rutin dan berulang. Karena bagi masyarakat ini, menghasilkan ide merupakan hal yang harus dilakukan untuk kemajuan.

Ekonomi kreatif menjadi katalisator bagi pertumbuhan ekonomi Indonesia di tengah perlambatan pertumbuhan ekonomi saat ini. Atas visi tersebut, pada 20 Januari 2015, lembaga baru mulai disahkan melalui Peraturan Presiden Republik Indonesia Nomor 6 Tahun 2015 Tentang Badan Ekonomi Kreatif. ${ }^{4}$ Presiden Joko Widodo percaya bahwa ekonomi kreatif kelak menjadi tulang punggung perekonomian Indonesia.

Momentum ini tidak hanya berlaku bagi pelaku usaha menengah atas, bahkan sangat terbuka bagi Usaha Mikro Kecil Menengah. Dengan demikian pengupayaan terhadap kesejahteraan masyarakat semakin terbuka lebar. Pertanyaanya, seberapa besar kepedulian dan kesungguhan para pemegang kekuasaan untuk berwirausaha dengan semangat kesejahteraan bagi seluruh rakyat Indonesia?

\section{Generasi Milenial}

Sejak mereka disekolahkan, sebagian besar anak laki-laki dan perempuan milenial dididik untuk berpartisipasi dalam olahraga tim, kelompok bermain, dan kegiatan kelompok lainnya, baik dalam organisasi atau komunitas. Mereka menghargai kerja tim dan mencari masukan sebagai penegasan jati diri. Generasi Millenial adalah generasi tanpa meninggalkan rekan kerjanya, setia, dan berkomitmen. Mereka secara Bersama-sama ingin terlibat dan dilibatkan. (Sumber: https://www.thebalancecareers.com)

\footnotetext{
${ }^{2}$ https://www.merriam-webster.com/dictionary/incubator, diakses pada 1 Juli 2019 pukul 10.00.

${ }^{3}$ Howkins, John (2001). The Creative Economy: How People Make Money from Ideas. London: Penguin.

${ }^{4}$ http://www.bekraf.go.id/profil, diakses pada 23 Januari 2019 pukul 13.55.
} 


\title{
Tinjauan Pustaka: Kerangka Teoritis
}

Tipe dan Perilaku dalam Arsitektur

Perilaku merupakan tindakan atau tanggapan seseorang terhadap subjek atau objek di lingkungan sekitarnya. Menurut Yoshiharu Tsukamoto dan Momoyo Kaijima dalam buku 'Behaviorology', perilaku dapat menjadi inti dari hipotesis untuk memahami korelasi antara kehidupan manusia, alam, dan bangunan. ${ }^{5}$ Sebagai elemen buatan manusia, perilaku bangunan adalah bentuk respon terhadap perilaku manusia, alam, dan berbagai perilaku sosial, budaya, dan ekonomi.

Korelasi dan interaksi antara tipe dan perilaku menggambarkan peran arsitektur sebagai ekosistem perilaku yang kompleks. Ekosistem perilaku menampung berbagai kategori perilaku dalam suatu tempat, ${ }^{6}$ yang jejaknya terekam di dalam tipe. Dengan demikian, mempelajari tipe berarti juga mempelajari perilaku awal yang membentuk tipe tersebut sekaligus membuka peluang akan munculnya tipe baru dari perilaku yang kini. Sebagaimana disebutkan pada bagian sebelumnya, sebuah tipe selalu berada di ambang perubahan. Maka dari itu, arsitektur bukan hanya media yang menunjukan perilaku tetapi juga wadah yang menampung dinamika perilaku di dalam dan sekitarnya.

\section{Renewing Architectural Typology}

Mengeksplorasi kemungkinan tipologi arsitektur sebagai metodologi dalam menjawab masalah kesejamanan, justru memicu pemahaman baru serta keraguan atas esensi dari tipologi itu sendiri. Menelaah tipologi dengan konteks tersebut, menjadikannya sebuah proposisi terhadap perilaku masyarakat dan penggunaan bangunan yang menuntut perubahan. Untuk itu, cara melihat sebuah arsitektur harus turut serta diperluas dalam beragam kemungkinan yang ada. Menururt AOC Architects dalam sebuah diskusi 'Synthesizing a Participative Architecture' bahwa:

\begin{abstract}
...Although we are certainly interested in the possibilities of architecture that make inventive use of visual and spatial references to explore, or playfully subvert, and shared meaning; We mean that we are conscious of operating in a world in which social and political structures are continually called into question, beliefs and memories are slippery things, and space is not an inert backdrop, but a live site of meaning production - space is a cultural practice. ${ }^{7}$
\end{abstract}

Penerapan tipologi di Indonesia sendiri harus dipertanyakan. Secara historis ide keruangan arsitektur timur lebih mengedepankan kosmologi dibanding fungsionalitas yang justru dominan bagi arsitektur barat. Bagi arsitektur timur, aktifitas dan prilaku jauh lebih mendominasi pembentukan suatu ruang dan mendefinisikan keberadaan ruang tersebut. Namun sejak terjadinya kolonialisasi hingga globalisasi, gagasan perubahan dan penggunaan bersifat fleksibel dan tidak terlalu melekat pada akar dan gagasan ide dasarnya. Sehingga patut dipertanyakan kemudian, tipologi apa yang pantas untuk dijadikan sebagai acuan bagi arsitektur Indonesia sendiri? Mungkinkah sebuah tipe baru muncul atas perubahan perilaku di era milenial ini?

\section{Kesimpulan Tinjauan Pustaka}

Pembelajaran tipe dan tipologi, memampukan kita untuk dapat berpikir secara praktis kedalam sebuah konteks atas kegunaan, kebutuhan, dan faktor intangible lainnya sebagai sebuah ide. Ide tersebut memiliki cikal bakal dasar yang terus bertransformasi atas inovasi dari zaman ke zaman. Untuk itu penting mengkorelasikan ide tersebut dengan perilaku kesejamanan, seperti saat ini di era milenial yang turut merevolusi pengembangan tipe dan formulasi ide sebuah bangunan. Menariknya, masih diperlukankah sebuah typology didalam terapan sebuah desain masa kini?

\footnotetext{
${ }^{5}$ Tsukamoto, Y., dan Kaijima, M. Behaviorology (New York: Rizzli, 2010). Halaman 8

${ }^{6}$ Tsukamoto dan Kaijima, Loc.Cit., Halaman 11

${ }^{7}$ Tom Coward, Daisy Froud, dan lain-lain, Renewing Architectural Typology (New York,2013). Halaman 73
} 
Setidak-tidaknya pembelajaran ini menjadi modal awal yang perlu dipahami terlebih dahulu sebelum kita mengevolusikan buah pemikiran lain kedepan.

Ekonomi kreatif sebagai sebuah kegiatan, menjadi konteks pendukung yang bersifat lebih mengkerucutkan prilaku siapa yang ingin diidentifikasi kepada tipe dan tipologinya. Sehingga pada projek ini, hendak akan kita telaah lebih dalam, "Bagaimana dialog antara tipe dan perilaku membentuk sebuah ruang arsitektur baru di era milenial bagi para pelaku kegiatan ekonomi kreatif di Kota Jakarta?"

\section{METODE}

\section{Metode Riset: Rute Awal Pemikiran}

Titik awal keperihatinan seperti yang telah diutarakan pada bagian latar belakang harus dilanjutkan dengan kerangka pemikiran yang membangun. Seperti halnya proses pembangunan, metode diperlukan selaku bekisting dan rangka pembesian yang memperkuat gagasan konseptual selanjutnya. Berbicara mengenai manusia, sosial, dan keruangan, maka metode riset yang digunakan terdiri atas:

\section{Spatial Agency}

Spatial Agency adalah metode proyek yang menghadirkan cara baru dalam melihat bagaimana bangunan dan ruang dapat diproduksi. Metode ini mendefinisikan kembali apa dan untuk apa arsitektur itu, dengan menyajikan kemungkinan bagi praktik di masa depan yang didasarkan pada prinsip-prinsip keterlibatan dan kolaborasi etis. Kelompok-kelompok kepentingan maupun kolektif ikut dilibatkan dalam mengkalibrasi ulang nilai-nilai keruangan dalam kepedulian sosial-spasial yang lebih luas di lapangan, sehingga sebuah karya hendak menawarkan cara lain dalam melakukan arsitektur.

\section{Everyday Urbanism}

Everyday Urbanism adalah sebuah cara untuk membaca interaksi 'sehari-hari' di dalam ruang kota yang sangat dinamis dan kompleks. Mengidentifikasi sebuah urbanisasi, membutuhkan sudut pandang diskursif yang luas dari berbagai disiplin ilmu. Sebab kehidupan di tengah ruang kota mengandung begitu banyak makna yang tumpang tindih dan kontradiktif, baik secara intelektual, fisik, sosial, politik, ekonomi, dan eksperimental yang estetis. Sehingga mereka tidak pernah dapat direkonsiliasi menjadi satu pemahaman tunggal.

Hidup berkota adalah negosiasi terhadap produk yang lahir dari kekuatan-kekuatan sosial, budaya, politik dan ekonomi yang bekerja di lingkungan urban kontemporer. Ruang sehari-hari yang terjadi dalam ruang kota dapat menjadi semacam mesin untuk menggerakkan arsitektur kepada titik yang lebih bersemangat, spontan, penting, dan menarik. Everyday Urbanism ini dimulai dengan mempertanyakan: Sebagai ruang publik kota, karakter dan model ruang sosial seperti apakah yang terbentuk didalamnya? ${ }^{8}$

\section{Partisipatory Action Research}

Metode Partisipatoris merupakan cara mengumpulkan data atau informasi, dengan melibatkan semua pihak-pihak yang relevan dalam mengkaji tindakan yang sedang berlangsung. Menurut Ozanne dan Saatcioglu, merupakan suatu metode penelitian kolaboratif yang mencoba membantu individu maupun kelompok untuk memahami diri, melakukan refleksi tindakan dan meningkatkan kontrol terhadap tindakan/hidup guna mendorong terjadinya perubahan dan peningkatan kesejahteraan (Understanding What Participatory Action Research is, by Foeday, 2011). Sehingga dengan metode pencarian data ini, diharap mampu memperkuat landasan

\footnotetext{
${ }^{8}$ Agustinus Sutanto, The New Passer Baroe: The Heritage with Soul - A Great Civic Space, Sayembara Penataan Kawasan Pasar Baru, (Jakarta,2014). Halaman 4.
} 
pengajuan proyek yang awalnya diidentifikasi melalui metode everyday urbanism. Berikut merupakan cara-cara untuk memperoleh informasi dengan metode partisipatoris, yaitu:

A. Wawancara

Wawancara adalah teknik pengumpulan data yang dilakukan melalui tatap muka dan tanya jawab langsung antara peneliti dan narasumber.

B. Observasi

Observasi adalah metode pengumpulan data yang kompleks karena melibatkan berbagai faktor dalam pelaksanaannya. Metode pengumpulan data observasi tidak hanya mengukur sikap dari responden, namun juga dapat digunakan untuk merekam berbagai fenomena yang terjadi. Teknik pengumpulan data observasi cocok digunakan untuk penelitian yang bertujuan untuk mempelajari perilaku manusia, proses kerja, dan gejala-gejala alam.

C. Angket (Kuisioner)

Kuesioner merupakan metode pengumpulan data yang dilakukan dengan cara memberi seperangkat pertanyaan atau pernyataan tertulis kepada responden untuk dijawab. Kuesioner merupakan metode pengumpulan data yang lebih efisien bila peneliti telah mengetahui dengan pasti variabel yang akan diukur dan tahu apa yang diharapkan dari responden.

\section{Metode Desain: Memahat Buah Pemikiran}

Desain (Design is a plan or specification for the construction of an object or system or for the implementation of an activity or process, or the result of that plan or specification in the form of a prototype, product or process. -Wikipedia.com-) berarti proses perencanaan atau perancangan suatu objek yang bertujuan agar objek yang diciptakan memiliki fungsi, memiliki nilai keindahan, dan berguna bagi manusia. Dalam berarsitektur, metode dalam proses desain menjadi sebuah sarana yang memformulasikan buah kreatifitas. Tujuannya agar karya yang dihasilkan bukan merupakan sebuah hasil karya seni murni yang utuh, namun memiliki rumusan teknis yang mampu menjelaskan serta mempertanggungjawabkan bentukan desain yang dihasilkan.

\section{Against Typology: Hybridization of Architectural Programming}

Ketika pusat kota terus tumbuh dan terus mengalami revitalisasi yang berkelanjutan, semakin banyak permintaan akan perumahan, hiburan, ritel, ruang hijau, dan infrastruktur mengikuti dan, pada gilirannya, mendorong lebih banyak pertumbuhan. Ketika intensifikasi ini berlanjut, arsitektur yang mendukungnya mulai bergabung dan mulai menantang gagasan tentang batas seperti dinding partai yang memisahkan satu program bangunan dari yang lain atau jalan raya yang memisahkan satu lingkungan dari yang lain. Di pusat kota yang padat, semakin kurangnya ruang dan meningkatnya nilai tanah sering kehilangan kemewahan tipologi bangunan otonom, dan cukup sering, program yang berbeda dipaksa untuk bergabung ke dalam gedung yang sama.

Sudah saatnya untuk secara resmi mempertimbangkan anti-tipologi yang dihasilkan ketika program-program yang berbeda bergabung, seperti perumahan dengan bioskop, atau ritel dengan ruang keagamaan, atau jalan raya dengan kantor. Ketika densifikasi memaksa penggabungan ini, pertimbangan harus diberikan pada rekonsiliasi kombinasi dari programprogram yang berbeda pada skala perkotaan dan skala arsitektur. Bentuk dan ruang generatif apa yang muncul melalui hibridisasi?

\section{DISKUSI DAN HASIL}

\section{Analisis Tapak Perancangan Pemiihan Lokasi}

Lokasi yang dipilih terletak di Kelurahan Kebon Kacang, Kecamatan Tanah Abang, Jakarta Pusat dengan basis kegiatan ekonomi didalamnya. Dalam rencana tata ruang wilayah Jakarta, secara umum Jakarta Pusat diperuntukan sebagai pusat pemerintahan dan pergerakan roda ekonomi. Kawasan sentra primer Tanah Abang sendiri merupakan pusat kegiatan primer dengan fungsi 
pengembangan pusat perdagangan grosir skala daerah, nasional, hingga internasional. Hingga Kawasan kebon kacang sebagai wilayah permukiman yang dikelilingi fungsi perniagaan dan jasa skala kota.

\section{Alasan Pemilihan Lokasi}

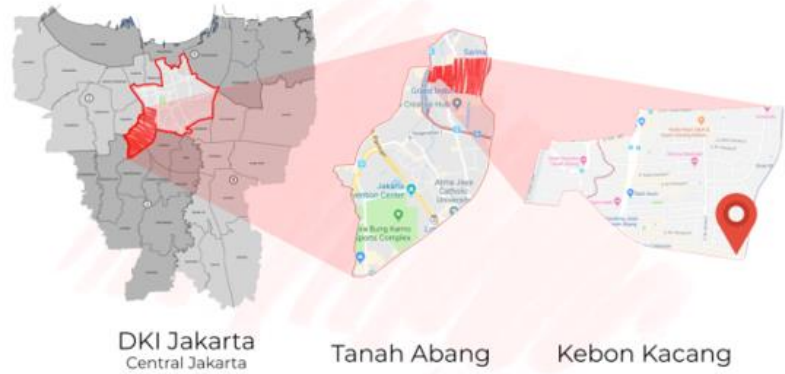

Gambar 1. Lokasi Tapak

Sumber: Penulis, 2019

Lokasi tapak perancangan dipilih atas dasar kontekstualitas ruang yang mampu menjawab rumusan masalah serta visi dari proyek ini. Menjadi salah satu keunikan tapak, sebab berada di antara kegiatan usaha yang bersifat individualistis, kapitalis, dan komersialis. Di sisi lain, terdapat kampung kota yang tengah menghadapi dominasi pembangunan oleh kelas sosial menengah keatas. Keberagaman lapisan masyarakat sebagai aktor dan pelaku kegiatan ruang sosial didalamnya menjadi semakin menarik. Sehingga cukup berpotensi dalam memberi tanggapan atas ruang arsitektur seperti apa yang dapat mengangkat kebutuhan pelaku kegiatan ekonomi kreatif kelas menengah-bawah, sekaligus mewadahi terjalinnya kolaborasi antar golongan sosial ekonomi yang berbeda.

\section{Data dan Profil Tapak}

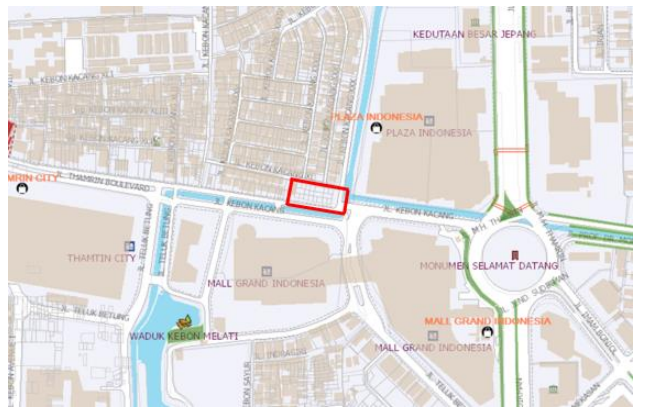

Gambar 2. Peta Lokasi Tapak Mezzo Sumber: https://jakartasatu.jakarta.go.id/

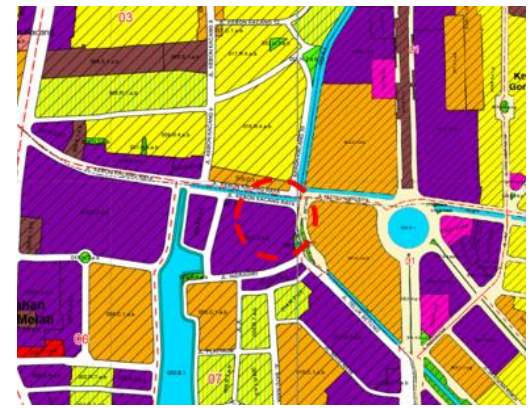

Gambar 3. Peta Zonasi Tapak Sumber: RDTR Jakarta Pusat

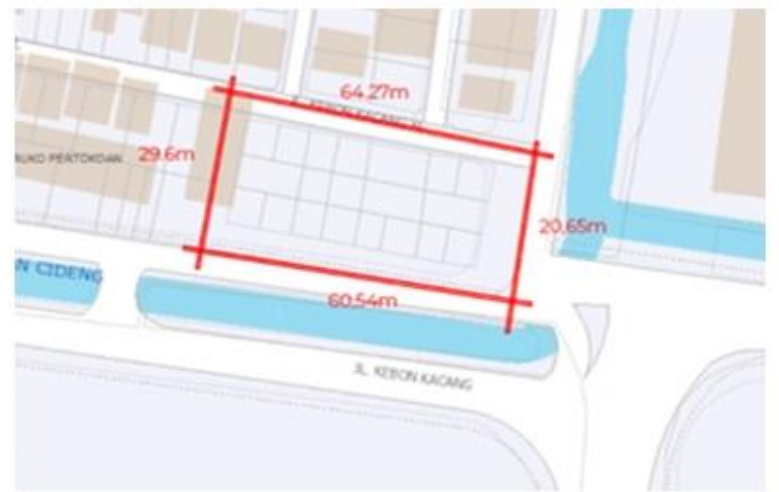

\begin{tabular}{ll}
$\mathrm{KDB}$ & $: 60$ \\
$\mathrm{KLB}$ & $: 2.4$ \\
$\mathrm{KDH}$ & $: 30$ \\
$\mathrm{~KB}$ & $: 4$ \\
$\mathrm{KTB}$ & $: 55$ \\
Tipe & $: \mathrm{D}$ \\
Zona & \\
\multicolumn{2}{l}{ ZONA CAMPURAN } \\
\multicolumn{2}{c}{ C.1 SUB ZONACAMPURAN }
\end{tabular}

Luas Tapak

$\pm 1.600 \mathrm{~m}^{2}$

Gambar 4. Peta Ukuran Tapak

Sumber: https://www.google.com/maps 


\section{Analisis Tapak}

Konektivitas dan Mobilisasi

Secara makro, dapat kita lihat bahwa tapak perancangan berada di lokasi dengan mobilisasi cukup strategis. Berada diantara dua Jalan Arteri primer yang menghubungkan Jakarta Pusat dengan Jakarta Barat dan Selatan. Pada Jalan M.H. Thamrin dan Sudirman, juga telah terfasilitasi moda transportasi umum seperti Bus Rapid Transit atau kita kenal Trans Jakata dan MRT yang akan diresmikan Maret mendatang.

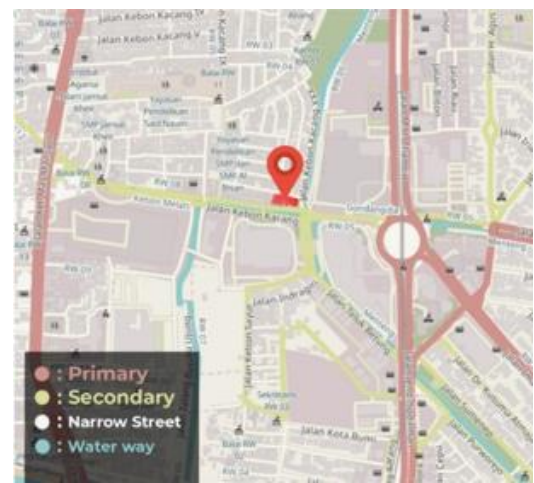

Gambar 5 . Humanitarian Map of Jakarta Sumber: https://www.openstreetmap.org/

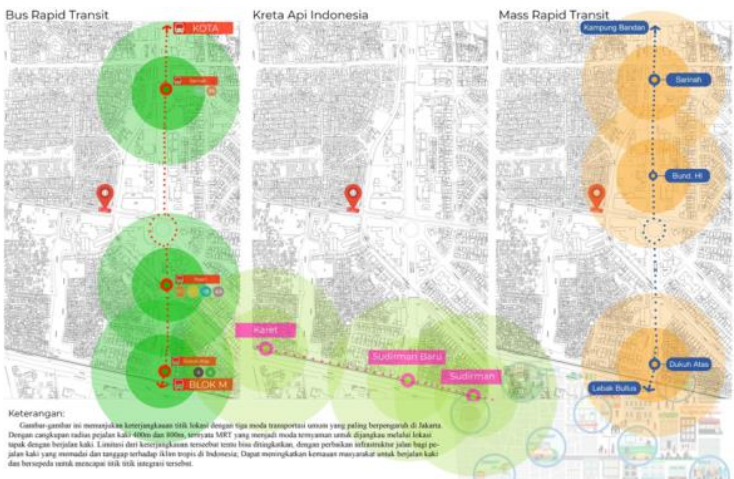

Gambar 6. Moda Transportasi Umum Sumber: Penulis, 2019

\section{Landmark dan Nodes}

Pemahaman terhadap landmark dan nodes pada lokasi terkait sangatlah dibutuhkan. Selain merupakan bentuk respon terhadap wilayah yang kita jajaki, kedua element ini justru hendak membantu kita dalam memberi pertimbangan-pertimbangan dalam proses desain bentuk yang akan dilakukan. Hal-hal yang bisa diperoleh dari melihat kedua aspek ini ialah hirarki, vista, continuitas, dan orientasi.

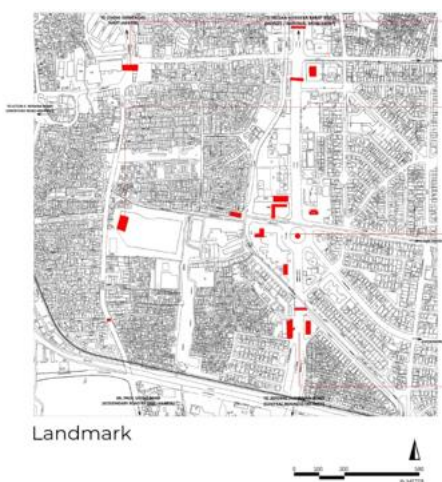

Gambar 7. Analisis Landmark Sumber: Penulis, 2019

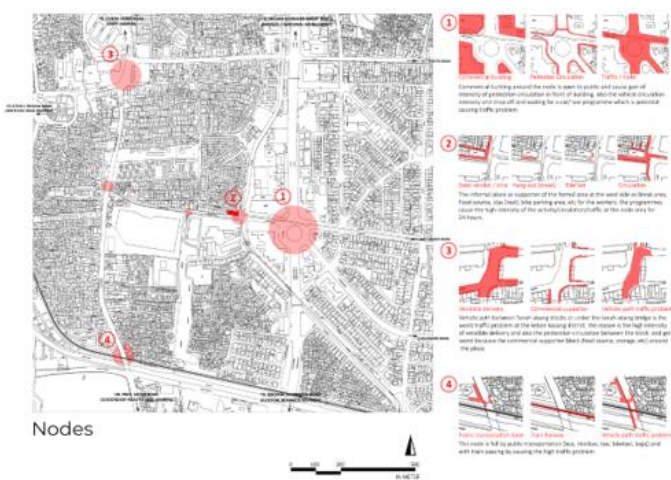

Gambar 8. Analisis Nodes Sumber: Penulis, 2019

\section{Tinjauan Lokasi Tapak}

Lokasi Tapak Berada di Jalan Kebon Kacang Raya No.1/5, RT 10 RW 004, Kelurahan Kebon Kacang, Kecamatan Tanah Abang, Jakarta Pusat. Pada lokasi tersebut, terdapat bangunan tua yang sudah lama tidak berfungsi secara baik dan berkelanjutan. Namun pada tepi-tepi jalan di depan tapak, merupakan nodes dengan aktifitas yang cukup besar dan rutin dilakukan antara pedagang kaki lima (pavement economy) dengan para pekerja kantor dan pegawai mall Plaza Indonesia dan Grand Indonesia yang menghabiskan waktu istirahatnya untuk mencari makan siang, sore, dan malam. 


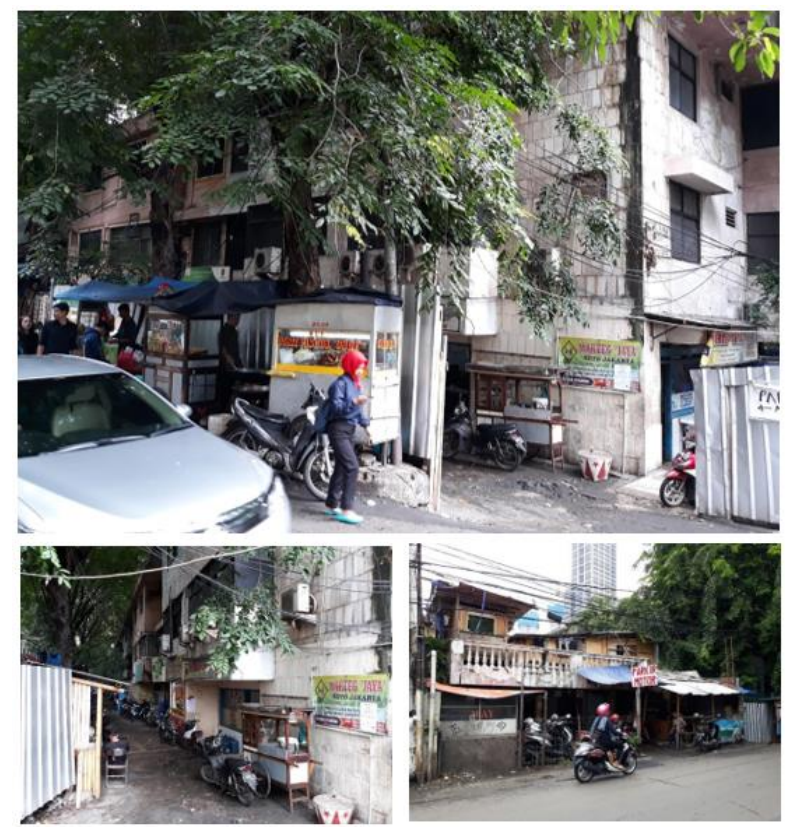

Gambar 9. Kondisi Tapak dengan Bangunan Tua atau Mati Sumber: Penulis, 2019

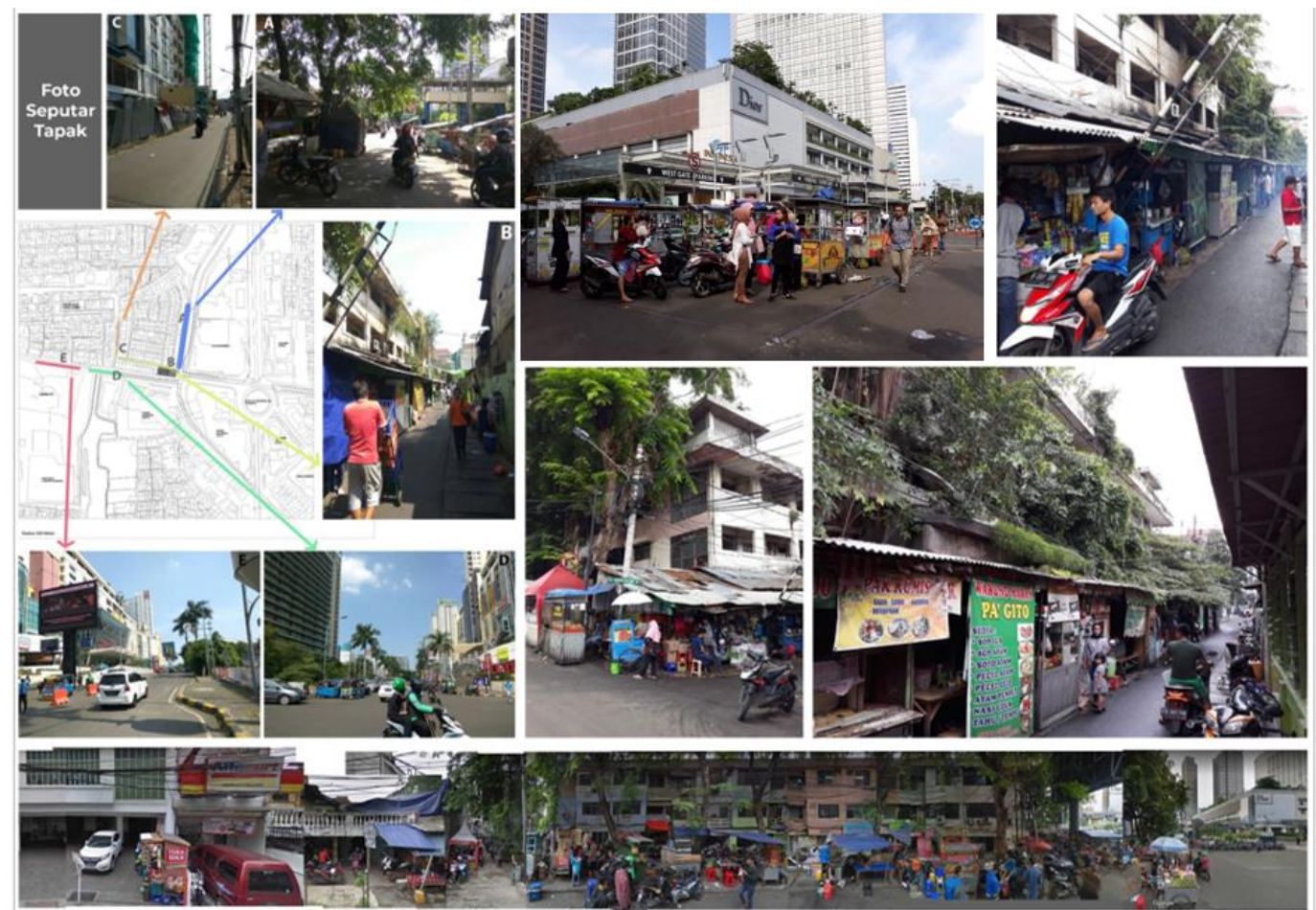

Gambar 10. Kondisi Sekitar Tapak dan Urban Life nya Sumber: Penulis, 2019

\section{Hasil Perancangan \\ Deskripsi Proyek}

Proyek pada tugas perancangan akhir ini ditentukan berdasarkan hasil riset di tapak yang telah dipilih menggunakan metode everyday urbanism. Melalui metode tersebut, diperoleh konteks yang kuat dalam mendasari jenis proyek yang ingin diajukan. Melalui pengamatan interaksi 'sehari-hari' terhadap aktor-aktor yang berkepentingan di kawasan Kebon Kacang, maka didapatlah indentifikasi aktifitas dan perilaku, seperti: 


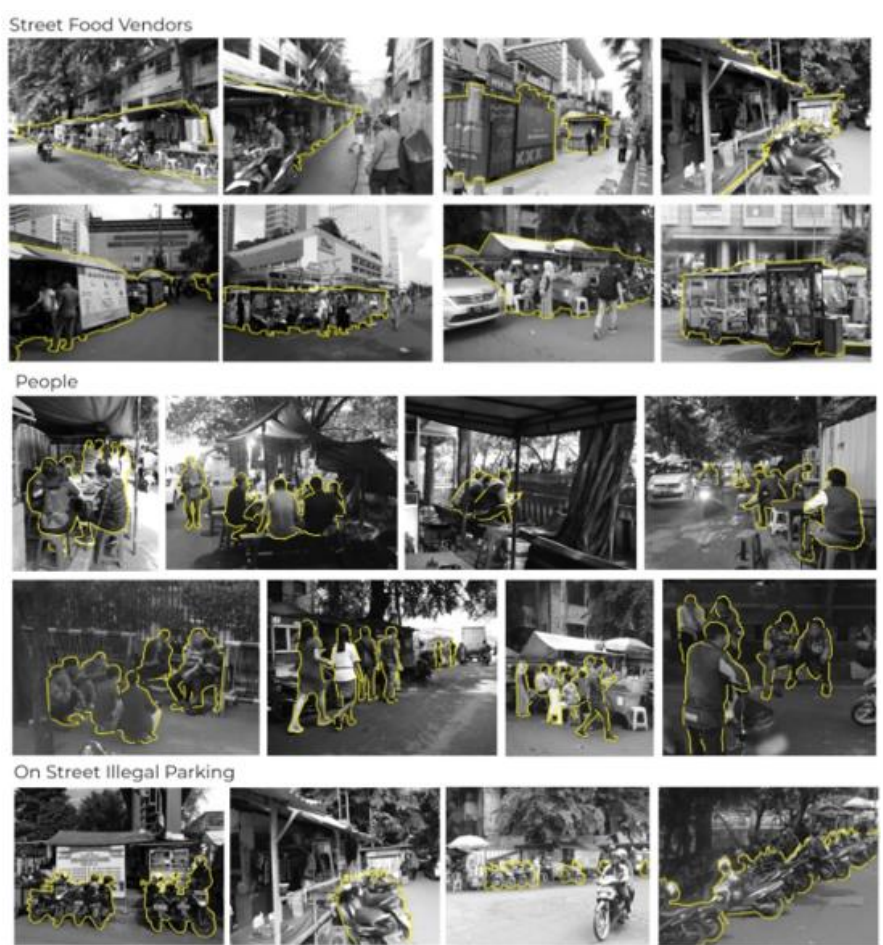

Gambar 11. Everyday Urbanism - Identifikasi Kegiatan dan Aktor Sumber: Penulis, 2019

Pedagang kaki lima, para pedagang informal, atau disebut juga pavement economy, sebagai subjek utama yang mempelopori aktivitas transaksi setiap harinya. Usaha mereka bergerak di bidang makanan dan minuman, mulai dari pukul 10 pagi hingga 12 malam bahkan lebih. Keberadaannya merupakan wujud negosiasi keruangan yang secara tidak disadari meleburkan kesenjangan ekonomi sosial disana. Menjadi salah satu aktor yang diambil dalam konteks perancangan ini karena memiliki peranan sebagai influencer atas terjadinya aktivitas di sebuah ruang kota.

Konsumen sebagai subjek kedua yang menjaga keberlangsungan aktivitas disana; kegiatan ekonomi informal sangat bergantung pada keberadaan konsumen (Hardjoko,2009). Mereka berasal dari para pekerja kantor, pegawai retail mall, hingga masyarakat yang berdomisili di wilayah kebon kacang dengan status kelas ekonomi menengah kebawah. Kebanyakan menghampiri lokasi untuk mencari makan di tiap jam istirahat kerja mereka atau sebelum ke tempat kerja sesuai waktu pergantian tiap-tiap pekerjanya. Kegiatan lain yang sering dilakukan adalah beristirahat atau sekedar minum sambil bersenda gurau ('nongkrong').

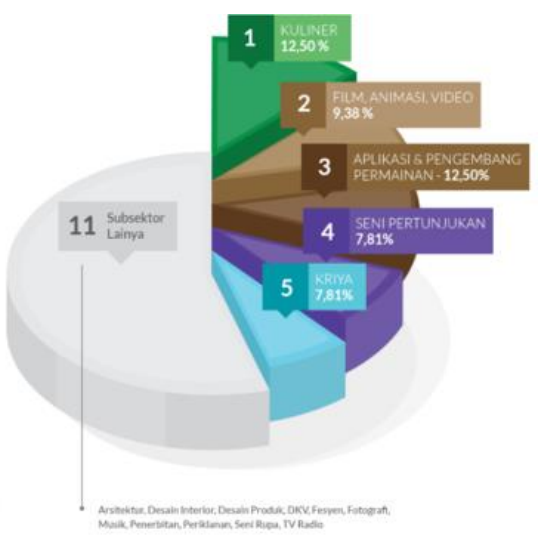

Gambar 12. Lima Subsektor E. Kreatif Sumber: Kata Kreatif: Langkah Jejaring Kota Kreatif Indonesia 
Adapun pelaku ketiga yang turut serta mengisi nodes ini hanya dengan duduk-duduk disepanjang bantaran kali, bahkan duduk berkelompok di jalur pedestrian. Sebagian besar dari mereka adalah para pengemudi ojek online yang menunggu pesanan terdekat dari mall dan kantor sekitar. Keberadaan mereka patut direfleksikan atas pentingnya menyediakan ruang publik kota yang selama ini terus diabaikan. Alhasil badan-badan jalan dikorbankan dengan begitu banyaknya illegal on street parking, yang mempersempit efektifitas pemanfaatan jalan sebaga sirkulasi kendaraan dan menciptakan citra kota yang tidak harmonis dan tertata.

Dari Ketiga partikel tersebut, konteks usaha makanan atau kuliner menjadi titik temu yang paling berpotensi untuk dikembangkan. Hal ini sejalan dengan konsep ekonomi kreatif yang sedang marak dikembangan. Apalagi berdasarkan buku laporan Badan Ekonomi Kreatif, 'Kata Kreatif: Langkah Jejaring Kota Kreatif Indonesia', 5 subsektor usaha kreatif terbanyak di Indonesia hingga saat ini adalah kuliner. Sehingga, didapatlah program keruangan yang saling berinterelasi satu sama lainnya, meliputi:

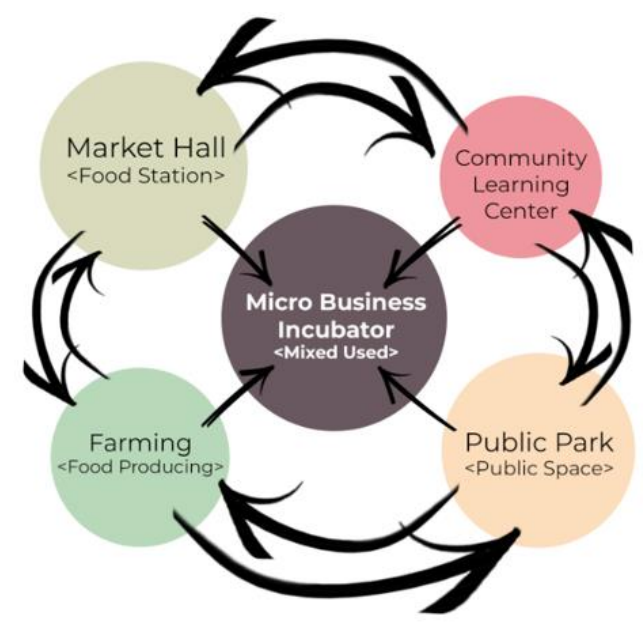

Gambar 13. Program dan Interelasinya Sumber: Penulis, 2019

\section{Market Hall as Food Station (40\%)}

Pada proyek ini, perencanaan keruangan area makan dan area pedagang dipisahkan dalam split level yang terhubung dengan sirkulasi ramp. Hal ini dilakukan sebab berdasarkan hasil observasi kegiatan konsumen yang makan, datang secara kolektif bersama rekan-rekan kerjanya yang memiliki preferensi makanan yang berbeda namun ingin duduk di meja yang sama. Selain itu, dengan pemisahan zona ini, terdapat pengupayaan ruang-ruang instagramable yang nyaman dan kunjung diminati para konsumen di kedai-kedai. Pertimbangan lainnya juga muncul akibat integrase system biogas yang diintegrasikan sehingga zona para penjual dibuat terpisah namun memudahkan penyaluran utilitasnya.

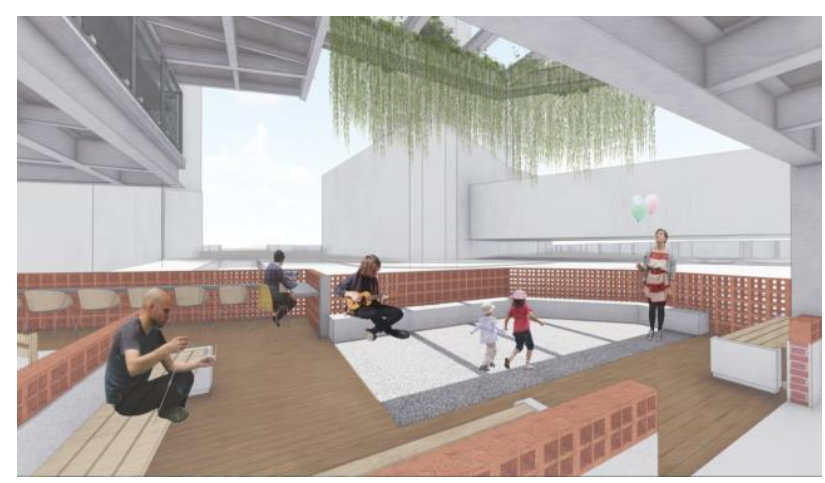

Gambar 14. Area Makan Konsuen disertai Taman Kering Semi Outdoor Sumber: Penulis, 2019 


\section{Farming as Self Food Producing (20\%)}

Program ini muncul untuk mensuport keberadaan food market dalam menjawab tantangan sufficient dan sustainability pasar. Seperti pada wadah ekonomi kreatif lainnya, pemerintah menyediakan berbagai fasilitas penunjang demi keberlangsungan dan pengembangan kegiatan usahanya. Begitu pula program ini, dapat berupa perkebunan vertikal, guna memajukan usaha melalui keterjangkauan bahan pagan yang mereka olah untuk diperjual-belikan.

'Pertanian kota dalam skala ini (Mini Farm Project), memiliki potensi lain untuk meningkatkan kesadaran penduduk kota akan sumber makanan mereka melalui pertanian dan praktik-praktik berkelanjutan. Isu ketidaknyamanan terhadap amannya produksi makanan yang dilakukan ditempat jauh dangan proses kimiawi juga bisa lebih diredam dengan adanya wadah kegiatan ini. Sebab 'Mini Farm Project' itu sendiri yang bersifat transparan dan terbuka bagi siapa saja yang ingin datang dan tertatik untuk mempelajari proses pengolahannya.

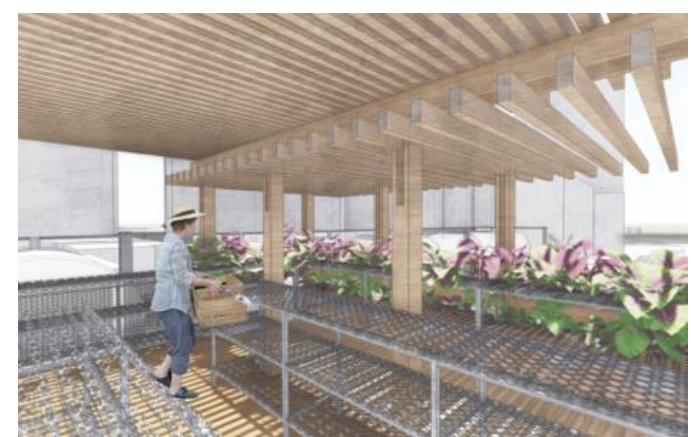

Gambar 15. Mini Farm Project for Self Sufficiency

Sumber: Penulis, 2019

\section{Community Learning Center (15\%)}

Sejak para milenial disekolahkan, sebagian besar anak-anak dididik untuk berpartisipasi dalam olahraga tim, kelompok bermain, dan kegiatan kelompok lainnya, baik dalam organisasi atau komunitas. Program ini mencerminkan perilaku milenial yang senantiasa bekerja dalam kelompok dan tidak hanya ingin sekedar senang-senang dalam menghabiskan wakunya tanpa suatu pencapaian apapun. Begitulah Community Learning Center ini hadir, sebagai wadah masyarakat milenial berkumpul, bersosialisasi, dan belajar bersama.

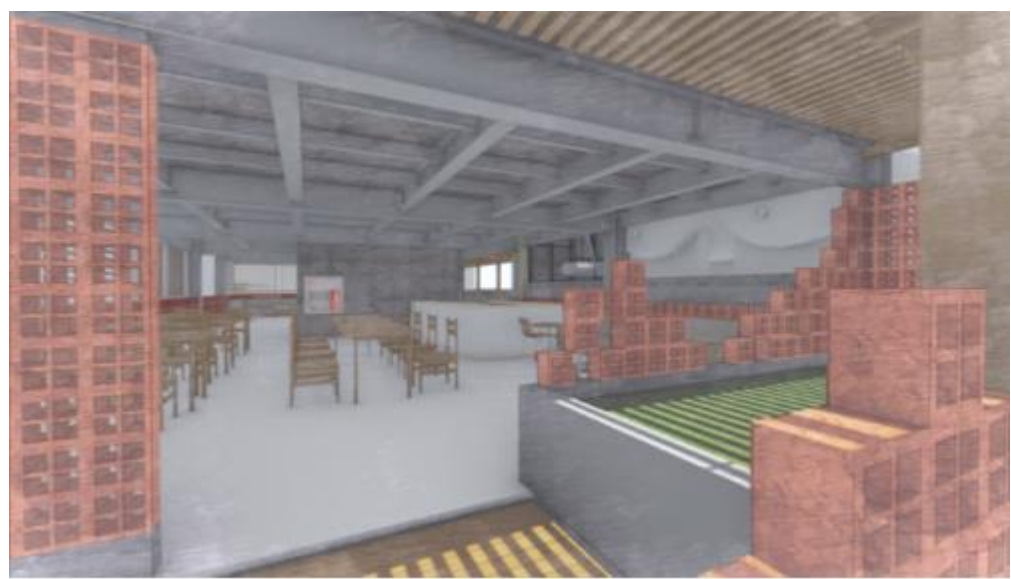

Gambar 16. Community based Area for Learning and Sharing Sumber: Penulis, 2019

Dalam korelasi dengan program lainnya, tempat ini dapat digunakan sebagai fasilitas para pengusaha makanan menengah bawah untuk mengembangkan ide dan kreasi makanan yang mereka jual. Fleksibilitas ruang sangat diperlukan agar berbagai kegiatan belajar-mengajar seperti sharing, workshop, hingga diskusi kelompok dapat dilakukan. 


\section{Public Space (25\%)}

Untuk menjawab kebutuhan ruang publik yang begitu langka di Jakarta, program ini turut dihadirkan. Sesuai dengan riset 'everyday urbanism' yang telah dilakukan, banyak sekali masyarakat yang membutuhkan ruang terbuka publik sebagai wadah mereka bersosialisasi namun tidak terwadahi. Juga sebagai respon dari berkembangnya ojek online yang mebutuhkan tempat-tempat tunggu. Dengan adanya program ini, scara tidak langsung memberi kenyamanan bagi pelaku pesan antar makanan dan berkontribusi dalam memberantas kesemerawutan kota.

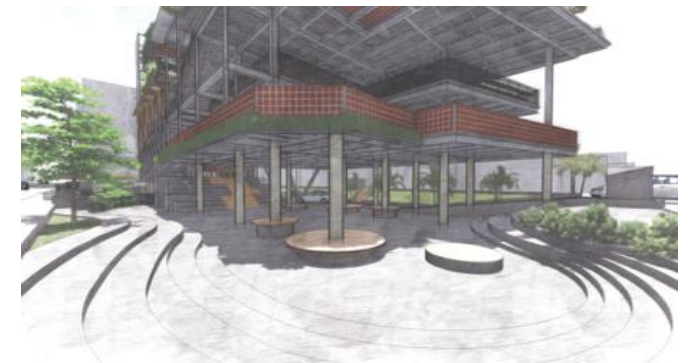

Gambar 17. Open Public Space Sumber: Penulis, 2019

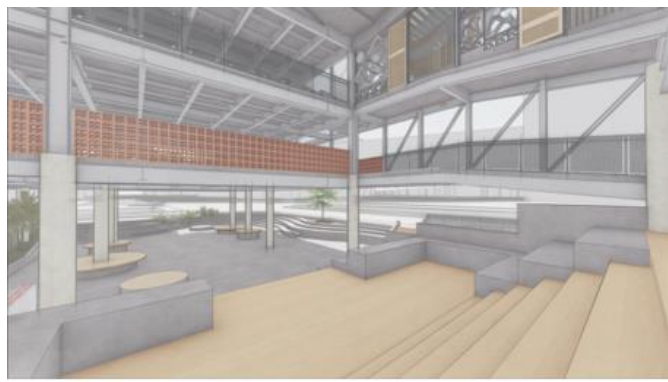

Gambar 18. Social Staircase

Sumber: Penulis, 2019

Penurunan pale lantai dilakukan mengikuti kondisi eksisting dan memaknai keberadaan banguan ini sebagai bagian dari kota itu sendiri. Ruang ini juga bersifat fleksibel, dapat digunakan sebagai tempat makan, sosialisasi, dan rekreasi bahkan nonton barenng sekalipun yang terbuka bagi siapapun dan adaptif mengikuti prilaku masyarakat yang begitu ditentukan dengan trending sosial media (place making).
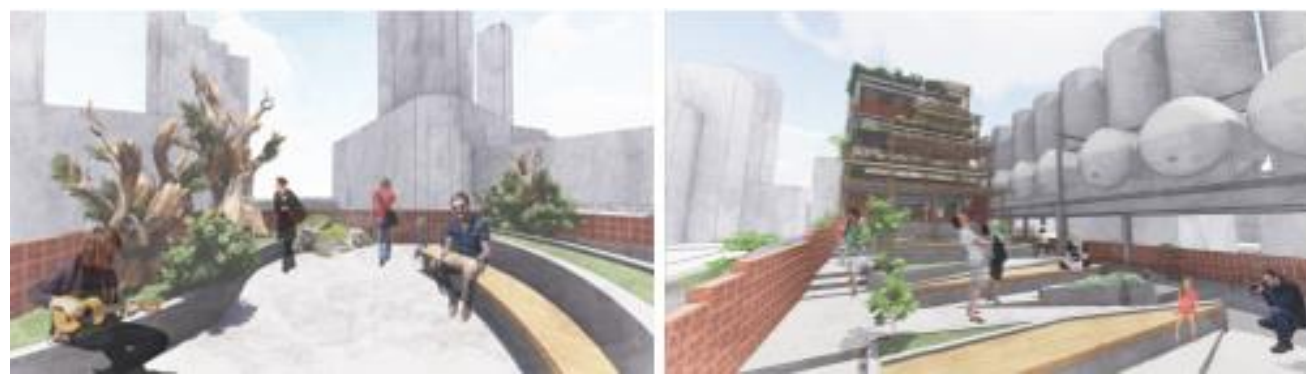

Gambar 19. Sky Garden

Sumber: Penulis, 2019

Diakomodasi dengan berberapa ruang temu sosialisasi seperti 'sosial staircase' yang menggandakan fungsi sarana transportasi vertical sebagai sebuah ruang komunal dan sangat efektif ketika terdapat kegiatan kebudayaan ataupun nonton bersama seperti halnya amphitheater. Dan dengan adanya 'sky garden' di lantai keempat, bertujuan sebagai magnet dari skala human di lantai dasar untuk menikmati simpang siur kota yang terjadi di persimpangan besar antara bangunan ini dengan Mall Plaza Indonesia dan Grand Indonesia.

\section{INKUBATOR KOTA}

Dalam pengertiannya proyek ini merupakan sebuah generator keruangan, yang hadir untuk mengembangkan, mengolah, dan mengupayakan lingkungan perkotaan disekitarnya berkolaborasi dan bersinergi. Hal-hal yang digenerasikan meliputi integrasi antar elemen perkotaan lama dan baru, pelaku-pelaku usaha informal, dan korelasi antara lingkungan buatan dan alam. Dari ketiga upaya tersebut, yang menjadikan proyek ini memiliki kompleksitas dari proyek biasanya adalah bagaimana kepekaan seorang arsitek, mampu mensinergikan keterhubungan sosial antara manusia yang berbeda status ekonomi-sosialnya sekalipun. 


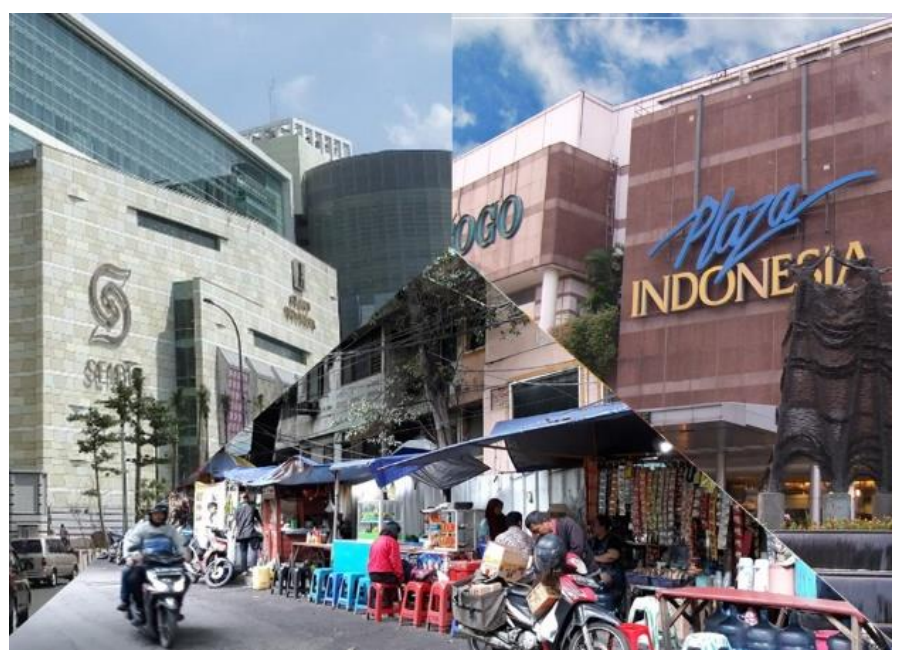

Gambar 20. Kontras Ekonomi-Sosial

Sumber: Penulis, 2019

Pernahkah anda merasa begitu prihatin melihat kesenjangan yang begitu luar biasa di suatu lokasi yang sama? Pernahkan anda mencoba untuk berpikir secara keras, peluang apa yag bisa dimanfaatkan agar terjadi timbal balik sosial secara tidak langsung sekalipun? Beranikah anda mencoba mendobrak pemikiran kapitalisasi yang menjadi candu dunia sampai saat ini?

Cara proyek ini menciptakan ikatan dan timbal balik yang kuat antara kontras dua status manusia, dengan melihat hal kecil yang tak bernilai seperti sampah. Pernahkan anda berpikir berapa besar sampah sisa makanan dibuang setiap harinya oleh sebuah mall? Adakah potensi yang bisa diambil dan secara arsitektural diselesaikan hingga mencapai kesejahteraan manusia? Sehingga dikembangkanlah konsep:

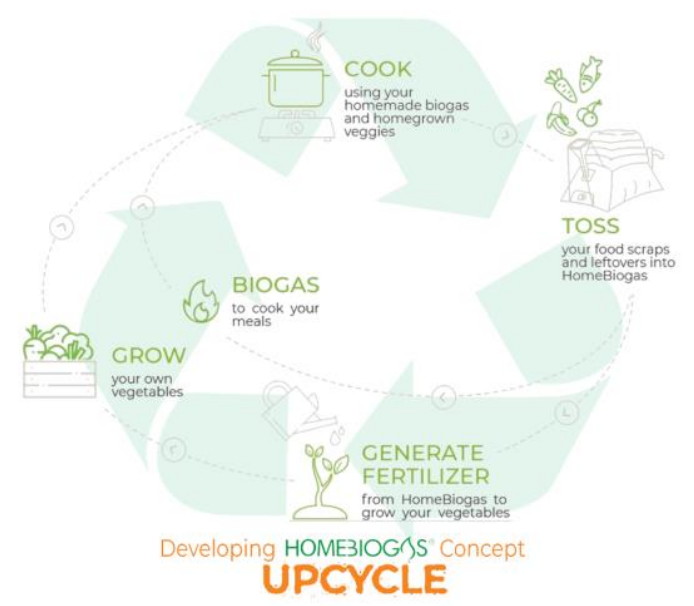

Gambar 21. Biogas as a Sprout of Big Idea

Sumber: HomeBiogas

Dengan sistem ini sebagai penggerak generator bangunan, terjalinlah timbal bailk antara pihak menengah atas yang cenderung membuang sisa-sisa makanan, dan inkubator bekerja mentransformasikan pengolahan sampah menjadi biogas dan fertilisasi media tanam. Keduanya digunakan untuk mensubsidi kebutuhan gas dan mensuport urban farm project dalam menghasilkan bahan pangan. Sehingga keterhubungan yang terjalin terjadi tanpa pemaksaan oleh kaum manapun. Dan Arsitektur mampu berperan sebagai sarana dalam mengupayakan kesejahteraan sosial. 


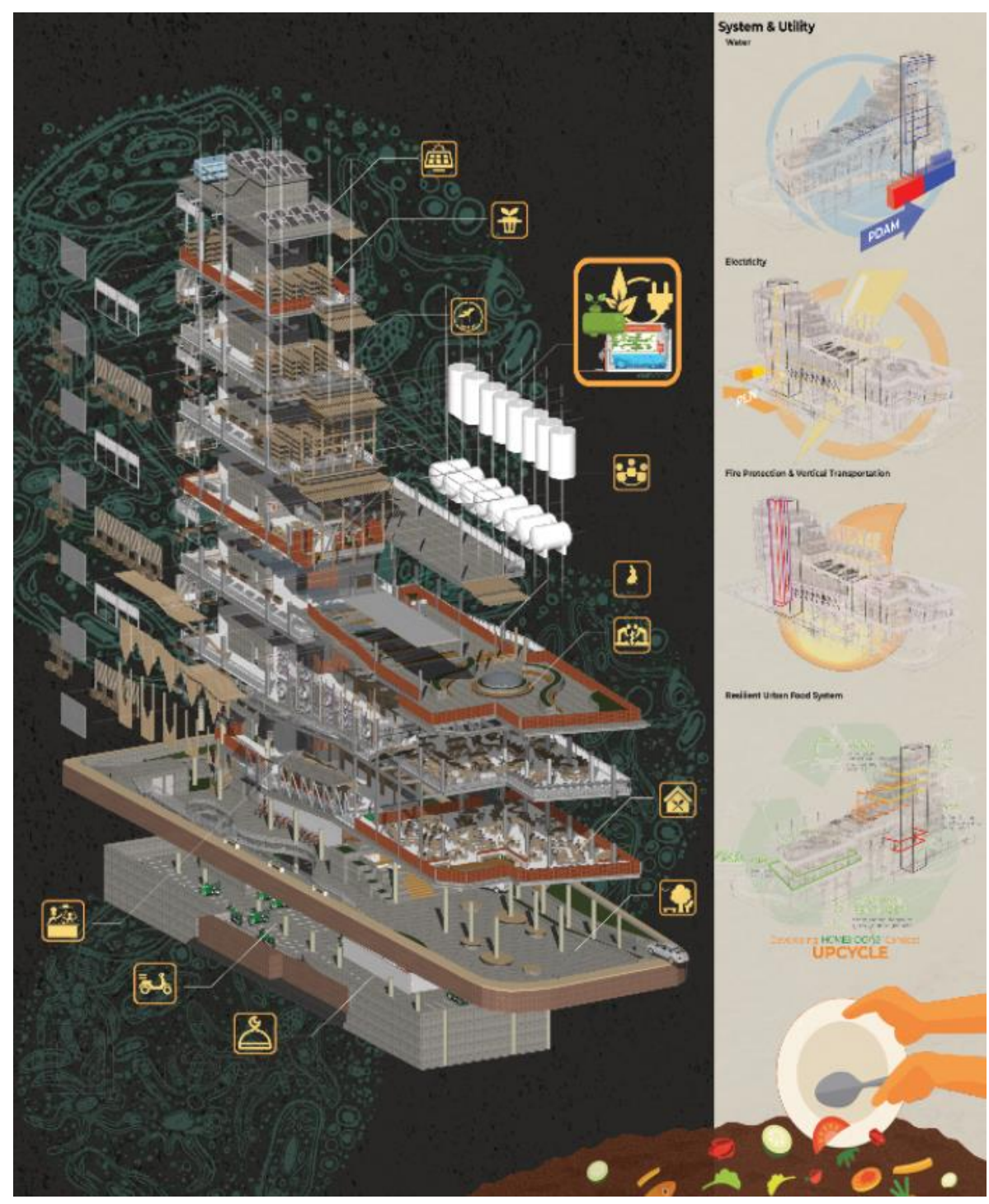

Gambar 22. Incubator Urbanism

Sumber: Penulis, 2019

\section{KESIMPULAN DAN SARAN Kesimpulan}

Dapat disimpulkan bahwa proyek ini merupakan sebuah prototype dengan konsep hybrid, yang memiliki latar belakang pengembangan bisnis eknomi kreatif di antara kegiatan usaha non-kreatif lainnya di kota metropolitan. Program didalamnya sangat tergantung pada kontekstualitas tapak yang telah didapatkan melalui metode 'everyday urbanism' berbasis spatial agency; Guna untuk melihat peranan arsitektur dari sudut pandang yang lebih luas dan sebagai bentuk usaha dalam meleburkan kesenjangan sosial ekonomi yang saat ini marak terjadi. Memang secara harafiah, arsitektur tidak akan dapat mensejahterakan ataupun menumpas kemiskinan. Akan tetapi, bagaimana arsitektur dapat turut serta memberikan sebuah ruang yang mewadahi kepentingan masyarakat menengah-bawah sebagai salah satu aktor nyata di kehidupan yang sering diabaikan.

Pada proyek ini, konteks ruang arsitektur yang diperoleh ialah ruang makan; Sehingga Food Market menjadi fungsi yang utama pada prototype ini. Sebuah program yang sangat sederhana, namun didapat berdasarkan kontekstualitas tapak melalui riset yang mendalam. Mereka yang makan di tempat ini adalah para pekerja kantor, pegawai toko dari mall Plaza Indonesia dan Grand Indonesia, dan karyawan yang merupakan kelompok masyarakat ekonomi menengahkebawah. Menanggapi isuu ekonomi kreatif, projek ini senantiasa hadir untuk mewadahi pengembangan usaha kecil-menengah yang diposisikan berdampingan dengan kegiatan ekonomi 
kapitalis. Sehingga terjalinlah kolaborasi antar golongan sosial ekonomi baik secara mikro (antar pelaku usaha kecil-menengah) maupun makro (Terjalin hubungan saling membutuhkan antara wadah usaha kelas menengah-bawah dengan usaha kelas menengah-keatas).

Pesan moral dari proyek ini, dibutuhkan keberanian disertai semangat untuk menciptakan suatu karya yang baik dan berguna bagi kepentingan banyak orang. Sebab dunia tidak menjadi lebih baik dengan semakin banyaknya starchitect, sehingga jadilah good architect yang peka dan peduli terhadap kondisi lingkungan sekitar. Mulailah dari lingkungan yang paling dekat dengan anda dan coba luangkan waktu untuk berpikir bagaimana saya dapat membuat lingkungan tersebut menjadi lebih baik.

\section{REFERENSI}

Brillembourg, A., Feireiss, K., Klumpner, H. (2005). Informal City: Caracas case Munich: Prestel. Coward, T. Froud, D. (2013). Renewing Architectural Typology. New York.

Ekspor Ekonomi Kreatif 2010- 2016. Jakarta: Badan Pusat Statiistik.

Forty. (2000). Words and Buildings: A Vocabulary of Modern Architecture. New York: Thames dan Hudson. Howkins, J. (2001). The Creative Economy: How People Make Money from Ideas. London: Penguin.

Rendell, J. (2007). Critical Architecture. London: Routledge.

Schneider, T., Till, J. (2011). Spatial Agency: Other Ways of Doing Architecture. London: Routledge.

Tsukamoto, Y., dan Kaijima, M. (2010). Behaviorology. New York: Rizzli.

Walters, D. (2007). Designan Community: Charranes, Master Plans and Form-Based Podes. Oxford: Architectural Press.

Yasemin I. G. (2005). Type and typology in Architectural Discourse. USA: University of Michigan.

Yuval N. H., "Why Humns Run the World", diakses melalui reaman ulang TED Talks di Youtube, diakses pada 30 Januari 2019, pukul 08.20.

http://www.bekraf.go.id/profil, diakses pada 23 Januari 2019 pukul 13.55.

https://katadata.co.id/berita/2018/10/17/apa-kata-startup-ekonomi-kreatif-tentang-bekraf, diakses pada 23 Januari 2019 pukul 14.00.

http://www.marxists.org/archive/marx/works/1843/, diakses pada 11 Februari 2019 pukul 16.25.

http://pemudatataruang.or.id/index.php/publikasi/artikel/169-kota-kreatif-creative-city-dan-pengaruhkomunitas-bagi-kota-yang-kreatif, diakses pada 26 Januari 2019 pukul 12.10.

https://www.sheffield.ac.uk/architecture/research/space-politics/spatial-agency, diakses pada 12 Februari 2019 pukul 15.00.

https://whatis.techtarget.com/definition/millennials-millennial-generation, diakses pada 26 Januari 2019 pukul 15.30 . 